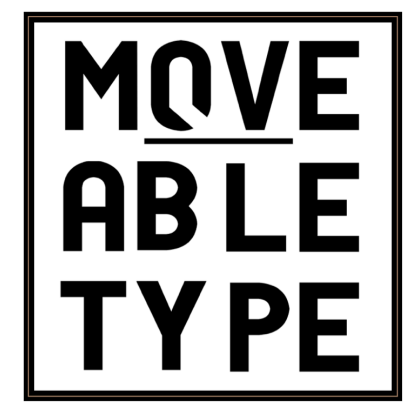

Enlightening the Marginalised: John Thelwall and the Value of Laughter Author[s]: Daniel Norman

Source: MoveableType, Vol.10, 'Peripheries' (2018)

DOI: $10.14324 / 111.1755-4527.080$

MoveableType is a Graduate, Peer-Reviewed Journal based in the Department of English at UCL.

(C) 2018 Daniel Norman. This is an Open Access article distributed under the terms of the Creative Commons Attribution License (CC-BY) 4.0https://creativecommons.org/licenses/by/4.0/, which permits unrestricted use, distribution, and reproduction in any medium, provided the original author and source are credited. 


\section{ENLIGHTENING THE MARGINALISED JOHN THELWALL AND THE VALUE OF LAUGHTER}

DANIEL NORMAN

In the first of his Political Lectures the radical orator John Thelwall, who had become a household name in the 1790s for his outspoken condemnations of Pitt's Tory government, reveals an underlying consciousness of the new political significance of laughter. Writing in early 1794 of the 1792 'Royal Proclamation Against Seditious Writings' (under which Thomas Paine's Rights of Man had been banned), Thelwall describes how

our looks [were] in reality called into question, and a seditious meaning [was] applied even to our very smiles; so that, in the midst of our other ALARMS, with which the nation was harassed at that period, I am informed that certain lovers of wit and pleasantry were in horrible apprehension lest it should be made CAPITAL to laugh without permission of his MAJESTY'S MINISTERS!!! ${ }^{1}$

Laughter, he emphasises, had become a politically dangerous act, given a new gravity by a government increasingly intent on prosecuting political radicals for sedition and treason. ${ }^{2}$ This is the cultural atmosphere within which one must contextualise the satirical elements of Thelwall's lectures. Far from representing a simple rhetorical tool, unthinkingly included by a skilful orator, they are in fact the product of considerable (and perhaps, given the political climate, unavoidable) reflection upon the nature and function of humour. By examining specific details within the lectures Thelwall delivered in the mid1790s, this essay seeks to throw new light upon Thelwall's perception and use of humour. The following argument will draw chiefly on the printed versions of lectures delivered between 1794 and 1795 in London, and published in his periodical The Tribune, arguing that Thelwall employs jokes not simply as rhetorical flourishes, but as a means by which

\footnotetext{
${ }^{1}$ John Thelwall, Political Lectures (No. 1): On the Moral Tendency of a System of Spies and Informers (London: D. I. Eaton, 1794), pp. 18-19; Jon Mee, 'Treason, Seditious Libel, and Literature in the Romantic Period', Oxford Handbooks Online (2016), 1-21 (p. 3).

${ }^{2}$ John Barrell, Imagining the King's Death (Oxford: Oxford University Press, 2000), p. 29.
} 
the politically side-lined and oppressed amongst his audience might be informed and educated. ${ }^{3}$

Thelwall's theatrical background provided him with an intrinsic awareness of the difficulty of holding an audience's attention, and an attendant grasp of the importance of entertainment. He had from the earliest part of his career directed his literary efforts towards the stage: Incle and Yarico, a farce written in 1787, and The Incas, an opera of 1792, had both been submitted to London theatre houses (the former to Haymarket, by then a patent theatre, and the latter to Covent Garden). ${ }^{4}$ Performance, and the demands of a paying audience, were thus realities with which Thelwall was well-acquainted in the years before he began his political lectures, and (as a regular theatre-goer himself) he would have had frequent first-hand experience of the boisterous and occasionally violent behaviour of the assembled crowds. ${ }^{5}$ Both Haymarket and Covent Garden had been the sites of numerous riots in the decades leading up to Thelwall's association with them (the most notorious occurring in 1738 and 1763 respectively), and by the 1770s the management of the London patent theatres had resorted to installing metal spikes in front of the stage, intended to prevent exuberant attendees from climbing up and assaulting the cast. ${ }^{6}$ Such crowds were not reluctant to make their dissatisfaction known.

Humour, as his writing of the early 1790 s makes plain, was a crucial weapon to be used in the fight to placate and subdue the fervour of these audiences. In early 1794 a comedy by Thomas Holcroft (a personal friend of Thelwall's) entitled Love's Frailties was

\footnotetext{
${ }^{3}$ Thelwall's lecture notes from this period have not survived; The Tribune constitutes the only source for their content.

${ }^{4}$ John Thelwall, Incle and Yarico and The Incas: Two Plays by John Thelwall, ed. by Frank Felsenstein and Michael Scrivener (Madison, NJ: Fairleigh Dickinson University Press, 2006), p. 14.

${ }^{5}$ Denyse Rockey, 'John Thelwall and the Origins of British Speech Therapy', Medical History, 23 (1979), 15675 (p.169).

${ }^{6}$ Judith W. Fisher, 'Audience Participation in the Eighteenth-Century London Theatre', in Audience Participation: Essays on Inclusion in Performance, ed. by Susan Kattwinkel (Westport, CT: Praeger, 2003), pp. 5570 (p. 57); Heather McPherson, 'Theatrical Riots and Cultural Politics in Eighteenth-Century London', The Eighteenth Century 43 (2002), 236-252 (p.237).
} 
performed at Covent Garden with a prologue attributed in the script to 'a literary friend.7

Subsequently identified in a contemporary review in the European Magazine as one 'Mr.

Thelwall,' this literary friend has been convincingly contended by Georgina Green to denote Thelwall himself. ${ }^{8}$ If the supposition is taken as valid, the prologue may be shown to reveal significant details regarding Thelwall's early attitude to the function of humour as a tool in performance and public speaking. Imagining the auditorium as an army, the actor (on the night a Mr Bernard) is prompted in parentheses to address the auditorium's various sections individually (firstly the pit):

Lo ruthless veterans rang'd, intrench'd chin deep!

Flanking this fearful centre in a ring, (Boxes)

Gay knights and Amazons form either wing!

Corps of reserve (Gallery) drawn up in dread array,

On yonder heights await the coming fray!?

Given the character of contemporary audiences, the comparison is perhaps not so fanciful as it initially appears, and Thelwall's parenthetical emphasis upon engaging the space reinforces his understanding of the need to form a direct bond with his physical audiences in order to keep their attention.

It is in the closing lines, however, that Thelwall depicts the strategies with which this attention is won (or lost):

Cassandra like, in black prophetic view, I see the massacres that may ensue!

Wit, humour, character, are put to rout!

The prompter breathless, and the actors out!

Quibbles and clap-traps in confusion run!

Slain is a sentiment! Down drops a pun! ${ }^{10}$

Thelwall is clearly drawing upon The Rape of the Lock here (which he had praised in his journal The Peripatetic a few months earlier), and more particularly upon the battle of Canto

\footnotetext{
${ }^{7}$ Thomas Holcroft, Love's Frailties (London: Shepperson and Reynolds, 1794), p. 1.

8 'Theatrical Journal', European Magazine, February 1794, pp. 137-38; Georgina Green, 'John Thelwall Author of the Prologue to Thomas Holcroft's Love's Frailties (1794)?', Notes and Queries, 55 (2008), 422-424.

${ }^{9}$ Holcroft, p. 1.

${ }^{10}$ Holcroft, p. 1.
} 
Three. ${ }^{11}$ Here too there are allegorical 'warlike' factions and 'routed arm[ies]' whose actions similarly result in the 'wild disorder' Thelwall also recounts. ${ }^{12}$ As with Pope, it may be argued that Thelwall cannot help but take a certain pleasure in the chaos; rather than condemning the exuberance of the event, he loses himself in the painting of it (lapsing, for example, into the quicker pace of the dactylic '[q]uibbles and clap-traps in confusion run'). Where The Rape's concluding moral consists of an intentionally tonally incongruous memento mori ('after all the murders of your eye, / [...] after millions slain, yourself shall die'), Thelwall instead continues to relish the use of humour within his concluding lines, taking a playful shot at Holcroft:

How shall our general dare such danger meet?

Were it not better, think you, sirs, to treat?

War honours grant then, as he files away;

So may he live and fight another day. ${ }^{13}$

It is plain that, for Thelwall, theatrical spectacle, with all the rowdiness and disorder it provoked, is a pleasure to be revelled in. At the heart of this joy, as the prologue makes clear, is the pivotal role of wit and good humour, with which he evidently engages with enthusiasm.

In his political lectures, the first of which was to take place only a few weeks after the writing of this prologue for Holcroft, something of the same underlying attitude may be discerned. It is particularly clear in the derision he pours upon those he criticises, an often vehemently mocking scorn frequently pointed out by critics as hypocritical. Judith Thompson, for example, writing of the nature of his oratorical style, describes the easilydrawn conclusion that he is 'indulging in the very vices of rant and cant that he attacks in

\footnotetext{
${ }^{11}$ John Thelwall, The Peripatetic, ed. by Judith Thompson (Detroit, MI: Wayne State University Press, 2001), p. 295.

12 Alexander Pope, Selected Poetry, ed. by Pat Rogers (Oxford: Oxford University Press, 1998), pp. 42-43.

${ }^{13}$ Holcroft, p. 1.
} 
his opponents. ${ }^{14}$ His 1790 s lectures are full of examples of such jeering derision, most frequently directed at Edmund Burke, and his advocacy, for example, of restricting

that very diffusion of information, the very mention of extending which to the Swinish Multitude, throws Mr. Burke into such paroxysms of frenzy!-'to be led otherwise than blindly,' says he 'the followers must be qualified, if not for actors, at least for judges; they must be judges also of natural weight and authority,'-not the factious authority of tyranny and wealth-but 'NATURAL WEIGHT AND AUTHORITY!!! ${ }^{15}$

The aggressively sarcastic repetition, hammering home his perception of the absurdity of Burke's phrase, reveals the emphatic approach to humour one might expect from the prologue writer of Love's Frailties. Thelwall's scoffs are almost audible behind what Thompson elsewhere refers to as the 'confrontational punctuation' of his printed lectures, and they certainly appear to undermine the strength of his censure of Burke's 'paroxysms of frenzy,' drawing attention to what some might construe as Thelwall's own. ${ }^{16}$

For Thompson the apparent hypocrisy here may, however, be resolved through an alteration of the manner in which one considers the audiences to which these lectures were delivered. A perception of Thelwall as a hypocritical and superficial demagogue relies, she asserts, 'upon a view of the audience as a passive and inflexible mob, lacking the intellectual and verbal resources to follow and interpret ironies, capable only of immediate, unthinking visceral response to sensational sounds and images. ${ }^{17}$ The growing literacy of the labouring classes (which, alongside a few interested attendees from other social classes, constituted the majority of Thelwall's audience) lends weight to Thompson's argument; radical literature sold extremely well amongst the growing labouring class reading public, who actively engaged with the large quantity of cheap

\footnotetext{
${ }^{14}$ Judith Thompson, 'John Thelwall and the Science and Practice of Elocution,' in Spheres of Action: Speech and Performance in Romantic Culture, ed. by Angela Esterhammer and Alexander John Dick (Toronto: University of Toronto Press, 2009), pp. 21-45 (p. 41).

${ }^{15}$ John Thelwall, The Tribune (London: J. Thelwall, 1795), I, p. 222.

16 Thompson, 'John Thelwall and the Science and Practice of Elocution,' p. 41.

${ }_{17}$ Thompson, 'John Thelwall and the Science and Practice of Elocution,' p. 42.
} 
political material available at this time. ${ }^{18}$ Thelwall's self-contradictory enthusiasm, if Thompson's assertion of his audience's greater 'verbal resources' and their ability to detect ironies is granted, may instead be argued to parody Burke's own hypocritical 'frenzy, for which he had already earned criticism from much of the radical community (Wollstonecraft notably emphasising the inconsistency in his advocating cool rationality in Reflections on the Revolution in France, whilst simultaneously 'foster[ing] every emotion till the fumes, mounting to your brain, dispel the sober suggestions of reason'). ${ }^{19}$ Thelwall's caustic humour, under this reading, may be interpreted as an indication of a deeper and more considered sarcasm within his approach to his subject matter.

Yet despite these apparent subtle parodies and inversions, and their appeal to intellectual engagement rather than 'immediate, unthinking visceral response,' the fundamental thrust of Thelwall's rhetorical technique largely operates on a more basic level. It must be remembered that many of his lectures were delivered in taverns (notably the Globe Tavern off the Strand), to animated, often singing, crowds. ${ }^{20}$ In turning to the substance of Thelwall's lectures in 1794 and 1795 it is clear that, contrary to an assessment of his apparent subtlety, immediate and instinctive emotional response was absolutely pivotal to his project. Laughter, instinctive almost by definition, provides the perfect case in point for this claim. Across Thelwall's lectures, the act of laughing is held up as a symbol of accurate and sincere moral judgement: the honest instinctual chuckle of an ordinary citizen is presented as anathema to corrupt and oppressive politicians. This attitude is particularly clear in his discussion of William Fitzwilliam (the fourth Earl Fitzwilliam) in a lecture of early May, 1795. Fitzwilliam, a Portlandite Whig, had

\footnotetext{
18 Gillian Russell, 'Spouters or Washerwomen: the Sociability of Romantic Lecturing', in Romantic Sociability: Social Networks and Literary Culture in Britain, 1770-1840, ed. by Gillian Russell and Clara Tuite (Cambridge: Cambridge University Press, 2002), pp. 123-144 (p. 125); Michael Scrivener, Seditious Allegories (University Park, PA: The Pennsylvania State University Press, 2001), p. 78; Michael Scrivener, The Cosmopolitan Ideal (Abingdon: Routledge, 2016), p. 55.

${ }^{19}$ Mary Wollstonecraft, $A$ Vindication of the Rights of Men, with $A$ Vindication of the Rights of Woman, and Hints, ed. by Sylvana Tomaselli (Cambridge: Cambridge University Press, 1995), p. 7.

20 Thelwall, The Tribune, I, 166.
} 
hesitatingly given his support to the Pitt-Portland Coalition of mid-1794, accepting Pitt's offer of the role of Lord Lieutenant of Ireland. ${ }^{21}$ Fitzwilliam was later recalled (as a result of his support for the extension of Catholic rights), and subsequently critiqued the prime minister, writing that ' $\left[\mathrm{I}\right.$ have] the glory of being objectionable to Mr. Pitt." ${ }^{, 2}$ Despite this, his acceptance of the Lord Lieutenancy was seen by Thelwall as a fundamentally selfinterested act, the moral bankruptcy of which could be precisely diagnosed in the ridicule his ignominious dismissal would attract:

to talk of the glory of being obnoxious to a man who has made you his tool and instrument to swindle Ireland of her men and money, and then throws you away with neglect and contempt, is language too ridiculous, [...] And to say afterwards that 'he has not rendered your character subservient to his views,' is talking that, at which children themselves would laugh. The very drivellers in the street would point their fingers at the man who could make use of such logic as this 'I have bargained for the wages of iniquity, and was refused my reward. I, therefore, stand up before the people and talk of my character, and glory in being made obnoxious to the being by whom I am thus disappointed. ${ }^{23}$

In order to understand the truth of the affair, in Thelwall's opinion, one need look no further than the laughing derision of ordinary people: even the intellects of 'children' and 'drivellers' are, through the medium of laughter, capable of grasping Fitzwilliam's moral failings. In this way, Thelwall presents the instinctive and immediate nature of honest laughter as a symbolic expression of an innate understanding of virtue, one that everyone, regardless of social status, possesses.

This attitude to laughter provides useful context for the satirical passages in Thelwall's lectures, casting light upon the way in which he intended them to function. It is vital not to underestimate the role of basic and instinctive human reactions to Thelwall's conception of moral virtue, and his satire conspicuously seeks to induce a basic and

${ }^{21}$ E. A. Smith, Whig Principles and Party Politics: Earl Fitzwilliam and the Whig Party, 1748-1833 (Manchester: Manchester University Press, 1975), p. 176-80.

22 Jeremy Black, George III: America's Last King (New Haven, CT: Yale University Press, 2008), p. 373; David Wilkinson, 'The Fitzwilliam Episode, 1795: A Reinterpretation of the Role of the Duke of Portland', Irish Historical Studies, 29 (1995), 315-339 (p. 316); William Wentworth Fitzwilliam, Observations on the Letters of Lord Fitzw-m to Lord Carlisle (Dublin: Thomas Burnside, 1795), p. 35.

23 Thelwall, Tribune, I, p. 219. 
universal instinctive reaction, of the kind he advocates in his discussion of the Fitzwilliam episode. This intention is most noticeable in his use of established Jacobin motifs, among which the image of the 'swinish multitude' is perhaps the most ubiquitous and wellknown. First used in Burke's Reflections to describe the threat posed by unruly commoners to 'the natural protectors and guardians' of learning (namely 'the spirit of a gentleman, and the spirit of religion'), the phrase provoked an immediate outcry. ${ }^{24}$ It became, as Darren Howard puts it, 'emblematic of a political philosophy that advocates a rigidly hierarchical social structure,' and was sarcastically adopted as an epithet by radicals themselves in such works as James Parkinson's An Address to the Hon. Edmund Burke from the Swinish Multitude and Daniel Isaac Eaton's periodical Politics for the People, or, A Salmagundy for Swine (to which Thelwall contributed) ${ }^{25}$ By exploiting the overt distinction between how their audiences saw themselves, and how the phrase suggested they were seen by the ruling classes, such authors deliberately manipulated the swinish motif for comic effect. For Thelwall too it represented a symbol whose prevalence (which ensured universal comprehension) made it a useful comic tool, and he enthusiastically adopts its basic premise throughout his 1795 lectures. In a lecture delivered on Friday, May 1st of that year, for example, Thelwall uses the image to criticise the government's role in causing the 'present DEARNESS and SCARCITY of PROVISIONS:'

They sent all the good corn out of the country, as fast as they could, to supply their good allies; and behold when they came to open their supplies [...] they found precious stocks of the stuff, the greatest part of which was obliged to be sold to the real swinish multitude: not to the two legged swine, but the real swinish multitude, who run on all fours. ${ }^{26}$

The humour here is not complicated, playing largely upon the ridiculousness of the image of 'two legged swine' (the italicisation perhaps denoting the comic emphasis with which he

\footnotetext{
${ }^{24}$ Edmund Burke, Reflections on the Revolution in France, ed. by L. G. Mitchell (Oxford: Oxford University Press, 1993), p. 79.

${ }^{25}$ Darren Howard, 'Necessary Fictions: The "Swinish Multitude" and the Rights of Man', Studies in Romanticism, 47 (2008), 161-78 (p. 161).

26 Thelwall, Tribune, II, p. 43.
} 
spoke the line) to underscore the absurdity politicians display in treating their citizens like (or indeed worse than) beasts. Just as Parkinson and Eaton had before him, Thelwall draws upon this simple and instantly recognisable image to form a joke in which all members of his audience may share, effectively and simply conveying how ludicrous he finds the government's actions to be.

At its core, the humour in these satirical appropriations of animalistic epithets lies in its straightforward irony; as Olivia Smith describes in The Politics of Language, radical authors like Thelwall were to a large extent simply 'pretending to be as their political opponents imagined them' for comic effect. ${ }^{27}$ Thelwall does not, however, make use of such images unthinkingly: upon closer inspection of his writing, a subtle attempt to build upon and reframe them becomes plain. This is not to say that he seeks to negate or correct the impact of the established metaphor, but rather that he attempts to harness its inherent comic value for a deeper moral purpose, one which is particularly conspicuous in his use of fish-related imagery. Though less popular than the swinish multitude trope, fish allegories were employed in a similar way within radical rhetoric, as may be seen, for example, in an anonymous contribution to the radical periodical Politics for the People:

the net of state power and cruel policy is cast abroad, even over the whole land; and we, like fish, are entangled therein, and blended with almost all the swine of Europe. $^{28}$

More of a flourish than a joke, the metaphor here follows the central thrust of the swinish trope by emphasising that governments are cruel because they treat their subjects like animals, and that (if the reasoning is taken to its obvious conclusion) humans ought to be treated better than fish or swine.

\footnotetext{
27 Olivia Smith, The Politics of Language, 1791-1819 (Oxford: Clarendon Press, 1986), p. 88.

${ }^{28}$ Daniel Isaac Eaton, Politics for the People: Or, A Salmagundy for Swine (London: D. I. Eaton, 1794), p. 58.
} 
When Thelwall adopts the metaphor, however, the underlying implication is fundamentally altered, as is particularly evident in his first Tribune lecture, where he asserts that

Circumstances [of] impolicy and injustice have produced an artificial scarcity of salt water fish: and a red herring which some years ago might be bought for a halfpenny, is not now to be had for less than threehalfpence or twopence.

When discussing the cause of this increase, Thelwall employs fish imagery in an unconventional manner (quoted here in full to demonstrate the cumulative effect of his style):

Will any man make me believe that the fishes are infected also with the rage of emigration?-Will you tell me that they also have drank the poisonous doctrines of jacobinism, and become discontented with that glorious constitution, under which for so many centuries they have so happily been eaten; and that, therefore, the herrings have fled from the coasts of Scotland, and the salmon deserted our rivers, and, together with the other factious inhabitants of our streams and shores, have fled, with atheistical abhorrence of all regular government, to the coasts of French anarchy, or the distant and happy shores of America, that they might enjoy the pleasure of being eaten without alloy from the consideration that they were put in the mouths of what they rebelliously consider as bondsmen and slaves? No, Citizens, it is the infernal spirit of monopoly, that cruel and wasteful demon that has rendered poverty, want, and distress the portion of the mass of the people of this country; that had produced in the midst of abundance this cruel, artificial scarcity.

Rather than founding his quip in the disjunction between humans and fish (as the Politics for the People piece had), Thelwall instead realigns it to focus on their similarities: just as it is ridiculous to argue that fish may act under Jacobin principles, so too is it ridiculous to impose the artificial limitations of monopoly upon humanity's relationship with the natural world. Our right to eat fish, Thelwall implies, is entirely natural and just, and any attempt to restrict or tamper with this right must appear as absurd as the suggestion that the natural behaviour of fish displays the influence of 'the poisonous doctrines of jacobinism.' By founding his argument upon a simple and recognisable humorous image, Thelwall is able to prompt deeper reflection within his audience: the natural moralising of their sense of humour (as he sees it) thus provides the ideal foundation for a more 
complex message about social justice. In this way, Thelwall's use of these commonplace radical motifs does not merely echo what Michael Scrivener calls the 'cultural insurgency' of radicals like Eaton; it seeks fundamentally to channel and redirect their radical energy. ${ }^{29}$

This channelling of humour provides a valuable key for understanding the wider nature of Thelwall's project in the Tribune lectures, and how he approached the task of lecturing itself. Writing in The Tribune's 'Farewel Address [sic.],' Thelwall outlines what in his view constitutes good oratory, emphasising the importance of 'fire of expression' and 'rapid energy of conception and arrangement. ${ }^{30}$ From passages like this it is possible to conclude, as Scrivener does in Seditious Allegories, that Thelwall felt effective lecturing to entail 'a necessary moment of "intemperance," and that, for him, 'the "soul of oratory" is spontaneous energy. ${ }^{31}$ Centring upon 'intemperance' to explain Thelwall's rhetorical style, however, stands intrinsically at odds with the way in which Thelwall himself understood and used this particular term. In the same way that he describes Burke's writing as the product of 'paroxysms of frenzy,' 'intemperance' is similarly used to denote a 'disordered imagination' or a debilitating mental chaos, something that 'the enthusiasm of weak minds is apt to produce. ${ }^{32}$ This is precisely the reverse of how Thelwall sought to communicate to his public, as his use of humour makes particularly clear. Though he does employ the underlying energy of simple Jacobin satirical motifs in order to provoke an instinctive response from his audience, he does not do so out of an unthinking paroxysm of enthusiasm. By prompting an instinctive response, Thelwall lays the groundwork for a deeper moral and political argument, harnessing an audience's laughter to underscore his ethical conclusions regarding politics and politicians. As he himself puts it, speaking about his lectures as a whole, his primary intention is 'to force my way to the conviction of your

\footnotetext{
${ }^{29}$ Scrivener, Seditious Allegories, p. 127

30 Thelwall, Tribune, III, p. 322.

31 Scrivener, Seditious Allegories, p. 169.

32 Thelwall, Tribune, II, p. 228.
} 
better judgements. ${ }^{33}$ This ambition goes some way to explaining the meaning of the assertion Scrivener dissects, namely that good oratory consists of 'rapid energy of [...] arrangement:' fire and wit alone are not enough, Thelwall intimates; they must be arranged in service of a higher goal.

Laughter, thus, lies at the core of Thelwall's moral and political project. It is clear from his earliest writing that Thelwall had a fundamental appreciation for wit, not only enjoying participation in communal laughter, but seeing laughter itself as an essential tool with which to win over an audience. His prologue to Holcroft's Love's Frailties reveals a conception of jokes as weapons to be used in the struggle to capture listeners' attention, and this same attitude fundamentally influences the approach he takes to his lectures. They feature a potent mixture of humour and declamatory rhetoric, aimed intrinsically to regale his audience, and thereby keep them interested. This intention does not, however, simply represent a superficial attempt to pull in attendees and revenue; Thelwall's oratorical style is wholly bound up with his political objectives. Laughter, for Thelwall, serves a critical role in the exposure of moral injustice: by mocking politicians, he highlights, one is able to expose their true colours, and to judge them accordingly. This capacity, possessed by all members of society, is the underlying target of the humour of his lectures. By provoking laughter, often using recognisable symbols and ideas to appeal to the largest possible proportion of his largely labouring class listenership, Thelwall lays a moral foundation. On this foundation he builds more complex political reasonings, many of which redirect the original significance of the images he employs, thus encouraging his audience implicitly to arrive at his intended conclusions themselves. Humour, in this way, represents the core of his 1795 lectures' purpose: by harnessing laughter, and the powerful radical energy it signifies, he is able to channel it into political arguments that are, for him, inherently morally justified. In this way Thelwall highlights that satire and mockery can

33 Thelwall, Tribune, II, pp. 2-3. 
communicate ethical criticisms not only entertainingly, but also persuasively and effectively.

\section{Works Cited}

Barrell, John, Imagining the King's Death (Oxford: Oxford University Press, 2000)

Black, Jeremy, George III: America's Last King (New Haven: Yale University Press, 2008).

Burke, Edmund, Reflections on the Revolution in France, ed. by L. G. Mitchell (Oxford: Oxford University Press, 1993).

Eaton, Daniel Isaac, Politics for the People: Or, A Salmagundy for Swine (London: D. I. Eaton, 1794).

Fisher, Judith W., 'Audience Participation in the Eighteenth-Century London Theatre', in Audience Participation: Essays on Inclusion in Performance, ed. by Susan Kattwinkel (Westport: Praeger, 2003), pp. 55-70.

Fitzwilliam, William Wentworth, Observations on the Letters of Lord Fitsw-m to Lord Carlisle (Dublin: Thomas Burnside, 1795).

Green, Georgina, 'John Thelwall Author of the Prologue to Thomas Holcroft's Love's Frailties (1794)?', Notes and Queries, 55/4 (2008), 422-424.

Holcroft, Thomas, Love's Frailties (London: Shepperson and Reynolds, 1794).

Howard, Darren, 'Necessary Fictions: The "Swinish Multitude" and the Rights of Man', Studies in Romanticism, 47/2 (2008), 161-78.

McPherson, Heather, 'Theatrical Riots and Cultural Politics in Eighteenth-Century London', The Eighteenth Century 43/3 (2002), 236-252.

Mee, Jon, 'Treason, Seditious Libel, and Literature in the Romantic Period', Oxford Handbooks Online (2016), 1-21.

Pope, Alexander, Selected Poetry, ed. by Pat Rogers (Oxford: Oxford University Press, 1998).

Rockey, Denyse, 'John Thelwall and the Origins of British Speech Therapy', Medical History, 23/2 (1979), 156-75.

Russell, Gillian, 'Spouters or Washerwomen: the Sociability of Romantic Lecturing', in Romantic Sociability: Social Networks and Literary Culture in Britain, 1770-1840, ed. by Gillian Russell and Clara Tuite (Cambridge: Cambridge University Press, 2002), pp. 123-144.

Scrivener, Michael, Seditious Allegories (University Park: The Pennsylvania State University Press, 2001), p. 78

— The Cosmopolitan Ideal (Abingdon: Routledge, 2016).

Smith, E. A., Whig Principles and Party Politics: Earl Fitswilliam and the Whig Party, 1748-1833 (Manchester: Manchester University Press, 1975).

Smith, Olivia, The Politics of Language, 1791-1819 (Oxford: Clarendon Press, 1986).

'Theatrical Journal', European Magazine, February 1794.

Thelwall, John, Incle and Yarico and The Incas: Two Plays by John Thelwall, ed. by Frank Felsenstein and Michael Scrivener (Cranbury: Associated University Presses, 2006). 
Political Lectures (No. 1): On the Moral Tendency of a System of Spies and Informers (London: D. I. Eaton, 1794).

The Peripatetic, ed. by Judith Thompson (Detroit: Wayne State University Press, 2001).

The Tribune, 3 vols (London: J. Thelwall, 1795).

Thompson, Judith, 'John Thelwall and the Science and Practice of Elocution,' in Spheres of Action: Speech and Performance in Romantic Culture, ed. by Angela Esterhammer and Alexander John Dick (Toronto: University of Toronto Press, 2009), pp. 21-45.

Wilkinson, David, 'The Fitzwilliam Episode, 1795: A Reinterpretation of the Role of the Duke of Portland', Irish Historical Studies, 29/115 (1995), 315-339.

Wollstonecraft, Mary, A Vindication of the Rights of Men, with A Vindication of the Rights of Woman, and Hints, ed. by Sylvana Tomaselli (Cambridge: Cambridge University Press, 1995). 